\section{Mathematics during the Festival of Britain}

THe College of Preceptors is holding in its premises at 2 and 3 Bloomsbury Square, London, W.C.1, an exhibition entitled "The Teacher: In School and Out", telling the story of developments in the teaching profession during the past hundred years. The Mathematical Association is participating in these events and, under the auspices of the London Branch, a "Mathematics Week" is being staged during July 9-13 (with the exception of Wednesday evening). There will be a comprehensive display of material used in mathematical teaching in educational institutions of all kinds, books from the Mathematical Association Library, outstanding numbers of the Mathematical Gazette, etc., and part of the Council Chamber will be set out and used as a classroom. Demonstrations and lectures will also be given. Admission is free. Further information may be obtained from Mr. B. J. F. Dorrington, 20 Montague Avenue, Brockley, London, S.E.4.

\section{Exhibition Awards}

THE Royal Commission for the Exhibition of 1851 has recently announced the following awards for 1951 (tenable for two or three years) for scientific research as shown. Senior Studentships (£600-650 a year), R. B. Dingle (Cambridge), theoretical physics at Cambridge; Dr. R. M. Goody (Cambridge), atmospheric physics at Cambridge; Dr. E. W. Simon (Oxford), plant physiology and biochemistry at King's College, London; F. G. Smith (Cambridge), radio astronomy at Cambridge. Overseas Scholarships (£350-400 a year), W. D. Jamieson (Dalhousie), physical chemistry at Cambridge; R. H. Hall (Toronto), organic chemistry at Cambridge; D. C. Weeks (Melbourne), plant physiology at Cambridge ; J. R. Cannon (Sydney), organic chemistry at Cambridge ; M. Spiro (New Zealand), physical chemistry at Oxford ; Dr. H. Rund (Cape Town), mathematics at Oxford; R. O. Colelough (Trinity College, Dublin), physical chemistry at Leeds; K. K. Pandey (Indian Agricultural Research Institute, New Delhi), cytogenetics at the John Innes Horticultural Institution, Bayfordbury; A. Husain (Dacca), nuclear physics at Glasgow.

\section{Lady Tata Memorial Fund: Awards}

THE following awards for research in blood diseases, with special reference to leukæmia, to be conducted in the places shown during the academic year beginning on October 1, have been made by the Lady Tata Memorial Fund: Grants for research expenses and/or assistance, Prof. Jørgen Bichel (Aarhus), Dr. G. Discombe (London), Dr. Astrid Fagraeus and Dr. Bo Thorell (Stockholm), Dr. N. G. Harboe (Copenhagen), Prof. C. Oberling (Paris), Prof. G. Schallock (Mannheim) and Dr. C. C. Ungley (Newcastle upon Tyne); Part-time personal grant, Dr. J. B. G. Dausset (Paris); Scholarships, Dr. Pascou Atanasiu and Dr. H. P. L. Febvre (Paris). In addition, a special fellowship has been awarded to Dr. A. R. Gopal-Ayengar, chief research cytologist at the Tata Memorial Hospital, Bombay, to enable him to work for a period at the Chester Beatty Research Institute, Royal Cancer Hospital, London.

\section{Summer School on the Physics of Solids}

A SUMmer School on the "Physics of Solids" will be held in the H. H. Wills Physical Laboratory in the University of Bristol during September 6-15. The course, which is similar in conception to those already held on the electrical and mechanical properties of solids, is being arranged by the Univer. sity and the Institute of Physies. It is intended mainly for research students at universities and for members of the staffs of Government and industrial laboratories who wish to familiarize themselves with the theoretical aspects of subjects with which they are concerned on the experimental side. Lectures will be given by Prof. N. F. Mott, Drs. F. C. Frank, D. Polder and R. Hill and other members of the University. The School will consist of three courses, on electron theory of metals (September 6-8), theory of the mechanical properties of metals (September 10-12), and macroscopic theory of plastic deforma. tions in metals (September 13-15). The last date for application to attend is July 1. Further particulars can be obtained from Mr. W. E. Salt, Director of Adult Education, University, Bristol, 8.

\section{Announcements}

Prof. Georges Guillain, professor of neurology in the University of Paris, has been elected a member of the Section of Medicine and Surgery of the Paris Academy of Sciences in succession to the late Prof. H. Vincent.

The following appointments in the University of London have been announced: Dr. Charles E. Dent, to the University readership in medicine tenable at University College Hospital Medical School from October 1; Dr. A. E. F. Moodie, to the University readership in geography tenable at Birkbeck College from October 1 .

Instructor Captain W. A. Bishop, director of the Educational Department of the Admiralty since July 1, 1948, has been given the title of director of the Naval Education Service, in view of the wider and greatly increased responsibility of the post since the War, and has been appointed instructor rearadmiral. As well as being head of the Instructor Branch of the Royal Navy, the director of the Education Service is responsible for the educational staffs of the Royal Naval Colleges and Royal Dockyard Schools.

The Second Pan-African Congress on Prehistory will be held in Algiers during September 29-October 4, 1952, with excursions during the fourteen days preceding September 29. Further details can be obtained from the organizing secretary, Prof. L. Balout, Bardo Museum, 3 rue Franklin D. Roosevelt, Algiers.

THe annual general meeting of the British Social Biology Council will be held at the Free Church Federal Council, 27 Tavistock Square, London, W.C.1, on July 10, at 2.30, under the chairmanship of Mr. L. J. F. Brimble. After the meeting, Dr. G. C. L. Bertram, director of the Scott Polar Research Institute, Cambridge, will give an address on population trends and world resources entitled "Multiplication for What ?" Further information can be obtained from Mrs. French (N.), British Social Biology Council, Tavistock House South, Tavistock Square, London, W.C.1.

In the article "The National Metallurgical Labor. atory of India" in Nature of February 24, p. 308, it was stated that Prof. Charles Crussard had taken charge of the Laboratory as director. Prof. Crussard has since resigned, and Dr. G. P. (not H. as printed) Contractor, assistant director of planning for the Laboratory, has been appointed acting director. 